\title{
A Study Of Consumer Behavior Of Elderly Consumers With Special Reference To Green Products
}

S. D. Singh, Magadh University, India

\begin{abstract}
This paper focuses on studying the consumer behavior of elderly customers for green products, the so called 'environmental friendly products.' The researcher also highlights the emerging awareness of elderly consumers about the green products. This concern has started showing the trends in their purchasing patterns. This paper also identifies the factors affecting their buying behavior.
\end{abstract}

Keywords: Green marketing; Green Products; Consumer behavior

\section{INTRODUCTION}

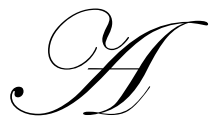

ccording to American Marketing Association(AMA), Green marketing is the marketing of products that are presumed to be environmentally safe. Thus, Green marketing incorporates a broad range of activities, including product modification, changes to the packaging as well as modifying advertizing. Hence, green marketing refers to holistic marketing concept wherein the production, marketing, consumption and disposal of products and services happen in a manner that is less detrimental to the environment. Overs the years, a majority of consumers have realized that their behavior had a direct impact on environment. There is a growing amount of evidence indicating that consumers are choosing products or avoiding others based on their impact on the natural environment.

Consumer behavior is the study of how people buy, what they buy, when they buy and why they buy. It blends elements from psychology, sociology, socio psychology, anthropology and economics. It attempts to understand the buyer decision making process, both individually and in groups. It studies characteristics of individual consumers such as demographics, psychographics, and behavioral variables in an attempt to understand people's wants. Belch and Belch define consumer behavior as 'the process and activities people engage in when searching for, selecting, purchasing, using, evaluating, and disposing of products and services so as to satisfy their needs and desires. The study of consumers helps firms and organizations in improving their marketing strategies.

\section{IMPORTANCE}

As the term "GREEN" is simply used to indicate concern with the physical environment (air, water, land). As resources are limited and human wants are unlimited, it is important for the marketers to utilize the resources efficiently without waste as well as to achieve the organization's objective. So, green marketing is inevitable. Nowadays, green marketing is creating markets for sustainable and socially responsible products and services. Now, it is the era of recyclable, non-toxic and environment friendly goods. This has become the NEW MANTRA for marketers to satisfy the needs of consumers and earn better profits too. Thus, green marketing is becoming a vital constituent of holistic marketing concept.

\section{OBJECTIVES OF THE STUDY}

This study is conducted with the following objectives. 
1. To study the consumer behavior of elderly consumers with special reference to green products.

2. To identify the factors that influences their buying decision.

Hypothesis: Green products are helpful in reducing global warming.

\section{RESEARCH METHODOLOGY}

For any research; deciding the sample size and sampling technique is an important part. There are various methods for deciding the sample size. For this study, the data collection was done by Convenience Random Sampling method. Based on the objectives of the study, the researcher decided to conduct the survey of elderly people between the age groups of 60-85. Researcher used Questionnaire method for collecting data. The questions were framed keeping in mind the objectives of research. The questionnaire was given to the elderly customers and the data was collected by personal interview in the form of written responses of the questionnaire. Total sample size for the customers is 100 . The first section of questionnaire was demographic data such as age, sex, qualification. The second section consists of purchase behavior items as well as their awareness about green marketing. For the analysis of the data, researchers used basic techniques of Statistics such as mean, standard deviation, variance, etc; Hypothesis Testing was done with the Chi-square test and certain non parametric tests too.

\section{Analysis Of Data}

Researchers mainly focus on the parameters which determines the buying behavior of elderly consumers, types of green products purchased by them. It also highlights the reasons why they purchase the green products. The detailed explanation of each parameter is as follows,

A) Awareness about Green Products: Related with this parameter, researcher asks questions with some options to the customer whether they are aware about green marketing and green products. It has been found that $\mathbf{8 5 \%}$ believe in green marketing whereas $\mathbf{5 2 \%}$ of customers actually purchase green products.

\begin{tabular}{|l|l|c|c|c|}
\hline \multicolumn{2}{|c|}{ Counts } & Yes & No & \\
\hline \multirow{2}{*}{ Labels -Gender } & Male & 38 & 18 & 56 \\
\cline { 2 - 5 } & Female & 34 & 12 & 46 \\
\hline \multirow{2}{*}{ Total } & 52 & 30 & 102 \\
\hline
\end{tabular}

B) Types of Green Products purchased by Elderly Consumers: In the research, it has been found that the elderly people buy different variety of environment friendly- green products.

TYPES OF GREEN PRODUCTS PURCHASED

ELECTRONICS

TOILETRIES AND COSMETICS PHARMACY

CLOTHING

- TRAVEL

AUTOMOBILES

FOOD DRNKS AND BEVERAGES

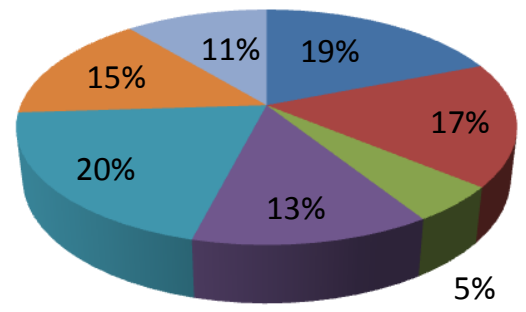


C) Factors affecting the buying behavior of Elderly Consumers: The researcher attempts to understand the motives which force the elderly people for buying the green products. It has been found that quality of green products $(35 \%)$ and the convenience $(31 \%)$ in buying them are the important reasons for their buying behavior.

D) Reasons behind companies' promotion of green products: The researcher also studies the underlying cause why companies promote green products. It has been found through the empirical study that the companies promote their green products in order to gain popularity $(22.5 \%)$ as well as to give back to the society. $(22.5 \%)$

\section{DATA ANALYSIS AND HYPOTHESIS TESTING}

Hypothesis: Green products are helpful in reducing global warming.

H0: Green products are helpful in reducing global warming.

H1: Green products are not helpful in reducing global warming.

Test Statistics: Green products are helpful in reducing global warming.

\begin{tabular}{|l|c|}
\hline & Believe Of Respondents In Green Products Reduces Global Warming \\
\hline Chi square & $65.922 \mathrm{a}$ \\
\hline df & 1 \\
\hline Asymp. Sign & .000 \\
\hline
\end{tabular}

Green Product Reduces Global Warming

\begin{tabular}{|l|c|c|c|}
\hline & Observed N & Expected N & Residual \\
\hline Yes & 92 & 51.0 & 41.0 \\
\hline No & 10 & 51.0 & -41.0 \\
\hline Total & 102 & & \\
\hline
\end{tabular}

0 cells $(.0 \%)$ have expected frequencies less than 5 . The minimum expected cell frequency is 51 . From Chi square test, it was found that the significance of green products in reducing the global warming lies within $5 \%$ level. Hence researcher accepts $\mathbf{H O}$ for green products which really help in reducing the global warming.

E) Reasons for not buying the green products: The researcher also tries to identify the reasons why customers do not buy the green products. It has been inferred that lack of information (66\%) stop them from buying the green products. Hence, marketers can take optimum efforts in communicating properly to the elderly people regarding the usage, benefits and other important information related to the green products.

\section{CONCLUSION}

The study provides interesting and potentially useful information about the consumer behavior of elderly consumers. Green Marketing is becoming a buzzword for the marketers. Thus, understanding of buyers' behavior is the key to success for the marketers. Marketers will have to understand the consumers' shopping behavioral dimensions of elderly people that will help them to tap the senior citizens in a better way. The elderly consumers are no doubt aware of the impact of their products on environment, even though their concerns are not translated into green consumer behavior. Green marketing should not be considered as just one more approach to marketing, but has to be pursued with much greater vigor, as it has an environmental and social dimension to it. With the threat of global warming looming large, it is extremely important that green marketing becomes the norm rather than an exception or just a fad. Recycling of paper, metals, plastics, etc., in a safe and environmentally harmless manner should become much more systematized and universal. It has to become the general norm to use energy-efficient lamps and other electrical goods. Marketers also have the responsibility to make the consumers understand the need 
for and benefits of green products as compared to non-green ones. In green marketing, consumers are willing to pay more to maintain a cleaner and greener environment. Finally, consumers, industrial buyers and suppliers need to pressurize effects on minimize the negative effects on the environment-friendly.

\section{AUTHOR INFORMATION}

Dr. Shiv Deo Singh has teaching experience of more than 26 years. His areas of interest are International Business, International Marketing Management and Marketing Management. He has written a book on the condition of management teachers in India. Dr. Singh has attended many national and international seminars/ conferences/ workshops and presented his papers. Dr. Singh had published more than 50 research papers in national and international journals. E-mail: sivdeosingh@yahoo.com

\section{REFERENCES}

1. Browns (1987) Institutional change in retailing: A review \& synthesis, Europeans of Marketing. 21(6) 536.

2. Gilbert D C (1990) The development of marketing - A compendium of historical approaches, Quarterly Review of Marketing 15-2, G13.

3. $\quad$ Gist R R (1968) Retailing Concepts \& decision, 196, New York Wiley \& Sons pg. no. 4-8.

4. $\quad$ Keith R. R., The Marketing Revolution.

5. Kristy E. Reynolds, Sharon E. Beatty (1999), Customer Benefits and Company Consequences of CustomerSalesperson Relationships in Retailing, Journal of Retailing, Volume 75(1), pp. 1132

6. $\quad$ Levy B. D. Weitz .A. P, The Retail management Strategies, McGraw Hill, New York.

7. Naresh K. Malhotra "Marketing Research, An Applied Orientation" Pearson Education, 2001,p 561-582.

8. Nelson, A C (2006) The Retailing Handbook. Oxford NTC Publications, London.

9. Sangman Han, Sunil Gupta, Donald R. Lehmann (2001), Consumer price sensitivity and price thresholds, Journal of Retailing 77 (2001) 435-456

10. Zimmer,M.R.Stafford,Thomas Stafford,M.R.(1994)Green Issues dimensions of environmental concern, Journal of Business research,30(1),63-74. 